Short Communication

\title{
Development of a Graphene Oxide-ZnO Nanorod Composite for Sensitive Determination of Catecholamine
}

\author{
Feng Zhang and Danni $\mathrm{Li}^{*}$ \\ Department of Neurology, Ji'nan Central Hospital Affiliated to Shandong University, Jinan, Shandong \\ Province, 250013, P.R. China \\ *E-mail: zxyylfzfeng@ sina.com
}

doi: $10.20964 / 2018.04 .42$

Received: 22 December 2017 / Accepted: 4 February 2018 / Published: 6 March 2018

\begin{abstract}
The present study proposed a facile hydrothermal method for the preparation of a reduced graphene oxide- $\mathrm{ZnO}$ ( $\mathrm{RGO}-\mathrm{ZnO}$ ) nanorod composite. A GCE modified by this nanocomposite was used for the determination of catecholamine (CA). The proposed biosensor showed a linear dependence on the CA concentration in the range of 1 to $800 \mu \mathrm{M}$. The limit of detection was obtained as $0.322 \mu \mathrm{M}$ based on the signal-to-noise ratio of 3. Furthermore, our developed biosensor proved highly stable and reproducible, with good anti-interference properties towards the detection of CA.
\end{abstract}

Keywords: Eosinophil cationic protein; Aptamer sensor; Graphene; Electrochemical determination; Childhood asthmatic attack

\section{FULL TEXT}

(C) 2018 The Authors. Published by ESG (www.electrochemsci.org). This article is an open access article distributed under the terms and conditions of the Creative Commons Attribution license (http://creativecommons.org/licenses/by/4.0/). 